\title{
PENGARUH TEKNIK PELVIC ROCKING DENGAN BIRTHING BALL TERHADAP LAMA PERSALINAN KALA I
}

Christin Hiyana TD $^{1)}$. Masini ${ }^{2)}$

${ }^{1,2}$ Dosen Prodi Kebidanan Magelang Poltekkes Kemenkes Semarang

Email/cp : christinhiyana@yahoo.com/085725241487

\begin{abstract}
ABSTRAK
Persalinan yang lama menyebabkan ibu mengalami stress dan kelelahan lebih lama sehingga rasa nyeri akan meningkat. Berbagai upaya fisiologis dilakukan untuk mencegah persalinan lama, seperti senam hamil, teknik nafas dalam, Pelvic Rocking dengan Birthing Ball yang mendukung persalinan membantu merespon rasa sakit dengan cara aktif dan mengurangi lama persalinan kala I fase aktif. Tujuan penelitian ini adalah untukmengetahui pengaruh teknik pelvic rocking dengan birthing ball terhadap lama persalinan kala I fase aktif.

Jenis penelitian ini adalah Pre Experiment dengan rancangan Statistic Group Comparison.Penelitian dilakukan di 2 BPM dengan sampel 15 ibu bersalin dengan teknik konvensional dan 15 dengan pelvic rocking dengan penilaian menggunakan Partograf. Data di analisis bivariat menggunakan uji Mann-Whitney Tes.

Hasil penelitian teknik konvensional $5(33,3 \%)$ orang mengalami persalinan lambat, 6 orang (40\%) normal, 4 orang (26,7\%) cepat. Persalinan dengan Pelvic Rocking dengan Birthing Ball $1(6,6 \%)$ orang mengalami persalinan lambat, 4 orang $(26,7 \%)$ normal, 10 orang $(66,7 \%)$ cepat. Hasil $p$-value sebesar 0,006, sehingga ada pengaruh Pelvic Rocking Dengan Birthing Ball terhadap Lama Persalinan Kala I Fase Aktif. Tenaga kesehatan yang memberikan pertolongan persalinan dapat menggunakan teknik Pelvic Rocking dengan Birthing Ball sebagai alternatif dalam mempercepat persalinan kala I fase aktif. Teknik Pelvic Rocking dengan Birthing Ball bersifatpraktis dan efektif dalam mempercepat proses persalinan kala I, sehingga dapat disosialisasikan kepada ibu hamil.
\end{abstract}

Kata kunci $\quad$ : Pelvic Rocking, Persalinan, Kala I

\section{THE INFLUENCE OFPELVIC ROCKINGTECHNIQUE WITH BIRTHING BALL ONLABOR PERIOD ON FIRST STAGE}

Long labor causes the mother to experience stress and fatigue for longer so that the pain will increase. Physiological efforts carried out to prevent prolonged labor, such as pregnancy exercises, deep breathing techniques, Pelvic Rocking with Birthing Ball that supports labor help respond to pain by actively and reduce labor time during the active phase. The purpose of this study is to determine the effect of birthing ball pelvic rocking techniques on the length of labor during the active phase.

This type of research is Pre Experiment with the design of Group Comparison Statistics. The study was conducted at 2 BPM with a sample of 15 maternity women with conventional techniques and 15 with pelvic rocking with an assessment using a Partograph. Data were bivariate analysis using the Mann-Whitney Test.

The results of conventional research 5 (33.3\%) people experienced slow labor, 6 people (40\%) were normal, 4 people (26.7\%) were fast. Labor with Pelvic Rocking with Birthing Ball 1 (6.6\%) people experience slow labor, 4 people (26.7\%) are normal, 10 people (66.7\%) are fast. The results of the p-value are 0.006, so there is the effect of Pelvic Rocking with Birthing Ball on the duration of labor during the first phase.

Health workers who provide childbirth assistance can use thetechnique Pelvic Rocking with Birthing Ball as an alternative in accelerating labor during the active phase. Thetechnique Pelvic Rocking with Birthing Ball is naturepractical and effective in speeding up the first stage of labor, so that it can be socialized to pregnant women.

Keywords $\quad$ : Pelvic Rocking, Labor, First Stage

BHAMADA, JITK, Vol. 10, No. 1, April 2019 


\section{PENDAHULUAN}

Persalinan adalah suatu proses pengeluaran hasil konsepsi (janin dan plasenta) yang cukup bulan atau dapat hidup di luar kandungan melalui jalan lahir atau melalui jalan lain, dengan menggunakan bantuan atau tanpa bantuan.(Sulistyawati, 2010).

Angka Kematian Ibu (AKI) di Provinsi Jawa Tengah pada tahun 2017 mengalami penurunan dari 109, 65 per 100.000 kelahiran hidup pada tahun 2016 menjadi 88,05 per 100.000 kelahiran hidup pada tahun 2017. Kematian maternal $60 \%$ terjadi pada waktu nifas, $26,32 \%$ pada waktu hamil dan sebesar $13,68 \%$ pada waktu persalinan (Profil Kesehatan Jawa Tengah, 2017). Hal ini menunjukkan, pentingnya pelayanan kesehatan maternal maupun perinatal yang berkualitas untuk menurunkan Angka Kematian Ibu (AKI) dalam rangka meningkatkan derajat kesehatan masyarakat (Profil Kesehatan Jawa Tengah, 2017).

Upaya pemerintah yang dilakukan untuk mengatasi kejadian partus lama (prolonged active phase) terdapat pada Permenkes Nomor 369/Menkes/SK/III/2007 tentang Standar Profesi Bidan yaitu sebagai profesi bidan diwajibkan memberikan pelayanan dalam asuhan kebidanan pada kala I persalinan seperti: pengaturan posisi, hidrasi, memberikan dukungan moril, pengurangan nyeri tanpa obat, memantau kemajuan persalinan normal dan penggunaan partograf serta memantau proses penurunan janin melalui pelvic selama persalinan dan kelahiran.

Pelvic Rocking dengan Birthing Ball adalah cara efektif untuk bersantai bagi tubuh bagian bawah khususnya daerah panggul yang merupakan usaha menambah ukuran rongga pelvisdengan menggoyang panggul dengan diatas bola dan dengan perlahan mengayunkan pinggul ke depan dan belakang, sisi kanan, kiri, dan melingkar.(Theresa Jamieson,2004)Pelvic rocking dapat membantu ibu dalam posisi upright, tetap tegak ketika dalamproses persalinan yang memungkinkan rahim untuk bekerja seefisien mungkin dengan membuat bidang panggul lebih luas dan terbukasehingga memudahkan kepala bayi turun ke dasar panggul.(Aprilia, 2011). Tujuan penelitian ini adalah untuk mengetahui pengaruh teknik pelvic rocking dengan birthing ball terhadap lama persalinan kala I fase aktif.

\section{METODE}

Jenis penelitian ini adalah Pre Experiment dengan rancangan Statistic Group Comparison. Sampel pada penelitian ini adalah semua ibu bersalin Kala 1 yang datang ke 2 BPM di Wilayah Kecamatan Secang Kabupaten Magelang selama bulan April Juni 2018. Pengambilan sampel dengan accidental samplingsejumlah 30 orang, dengan pembagian 15 orang dengan teknik pelvic rocking dan 15 orang dengan menggunakan teknik konvensional. Instrumen penelitian ini menggunakan Partograf. Analisa univariat 
untuk mengetahui prosentase lama persalinan kala 1. Analisis bivariat menggunakan uji Mann- Whitney Test.

\section{HASIL DAN PEMBAHASAN}

\section{a. Analisis Univariat}

1) Lama Persalinan Kala I Fase Aktif Dengan Teknik Konvensional

Tabel.1 Distribusi Frekuensi Lama Persalinan Teknik Konvensional

\begin{tabular}{lcc}
\hline Lama persalinan & Frekuensi & Persentase \\
\hline Lambat & 5 & 33,3 \\
Normal & 6 & 40 \\
Cepat & 4 & 26,7 \\
\hline Jumlah & 15 & 100 \\
\hline
\end{tabular}

Salah satu cara yang dapat dipilih dalam mempercepat proses persalinan kala Iadalah dengan pemilihan posisi tegak / upright position (Oxorn,2010) Posisi tegak salah satu yang dapat dipilih adalah dengan aktifitas duduk ataupun jalan - jalan selama kala I persalinan. Teknik ini tergolong sebagai teknik konvensional selain berbaring miring ke kiri.

Posisi tegak dengan berjalan - jalan ataupun duduk padaproses persalinankalaI diharapkan dapat memberikan keuntungan pada ibu maupun bayi, karena dapat memberikan relaksasi dan memberikan sedikit tekanan pada sirkulasi darah sehingga memberikan suplai oksigen pada bayi, selain itu posisi tegak juga dapat mempercepat penurunan kepala karena adanyagaya grafitasi bumi sehingga memperpendek waktu persalinan kala I. Wanita yang memilih posisi tegak, berjalan atau jongkok (uprightposition) merasakan kepuasan dan kenyamanan saat proses persalinan, posisi tegak juga memberikan kemudahan ibu untuk meneran. Dengan rasa nyaman yang dirasakan akan mempercepat proses persalinan.(Varney,2009)

Penelitian Wigand dan Leigh pada tahun 2012, pada ibu bersalin dengan hasil bahwa posisi tegak pada persalinan kala I fase aktif dapat memperpendek waktu persalinan lebih kurang 1 jam dan dapat memberikan relaksasi pada pembuluh darah dan juga dapat memberikan percepatan penurunan kepala karena adanya gaya gravitasi bumi sehingga dapat memperpendek kala I. Posisi tegak juga dapat meningkatkan kontrol diri terhadap rasa nyeri. Ada sedikit pengurangan tekanan pada sirkulasi darah sehingga memberikan suplai oksigen ke bayi lebih banyak yang sangat baik untuk ibu maupun bayi. Selain itu posisi tegak dengan jalan ataupun duduk dapat menjadikan gaya gravitasi lebih besar sehingga dapat mempermudah penurunan kemajuan persalinan karena janinakan beradapada posisi yang lebih baik untuk berjalan ke arah panggul ibu.Gerakan posisi berdiri dapat membantu mempengaruhi frekuensi, lamanya dan efisiensi dari kontraksi yang menyebabkan panggul terbuka lebih lebar dan memberikan ruang pada janin untuk segera keluar.

Kerugian dari posisi berjalan - jalan adalah ibu merasa mudah lelah karena membawa beban perut yang besar,dan beban yang dirasakan biasanya akan menambah nyeri yang dirasakan. 
2) Lama Persalinan Kala I Fase Aktif Dengan Pelvic Rocking dengan Birthing Ball

Tabel 2. Distribusi Frekuensi Lama Persalinan Teknik Konvensional

\begin{tabular}{lcc}
\hline Lama persalinan & Frekuensi & Persentase \\
\hline Lambat & 1 & 6,6 \\
Normal & 4 & 26,7 \\
Cepat & 10 & 66,7 \\
\hline Jumlah & 15 & 100 \\
\hline
\end{tabular}

Pelvic Rocking dengan Birthing Ball adalah gerakan menggoyang panggul dengan menggunakan bola persalinan. Pada saat proses persalinan memasuki kala I,duduk di atas bola dan dengan perlahan mengayunkan dan menggoyangkan pinggul ke depan dan belakang, sisi kanan-kiri, dan melingkarkan panggul akan menjadi lebih relaks. Gerakan ini digunakan untuk mengurangi rasa kurang nyaman pada saat proses persalinan dimana gerakan yang dilakukan ini ternyata memberi banyak sekali manfaat. (Aprilia,2011).Pelvic Rocking dengan Birthing Ball dapat dilakukan untuk mempercepat proses persalinan kala I dengan beberapa keuntungan, seperti memperkuat otot perut dan pinggang, mengurangi tekanan pada pinggang dengan menggerakkan tekanan ke depan secara sementara, mengurangi tekanan pembuluh darah diarea uterus dan mengurangi tekanan pada kandung kemih ibu serta memberikan pengurangan rasa nyeri untuk meningkatkan kenyamanana ibu pada proses persalinan. Kelebihanlain dari pelvic rocking yaitugerakanyangrelatifsederhanatidakmembut uhkanalat,tempatkhususdanpengawasankhusus .(Aprilia,2011)

Penggunaan birthing ball bisa dengan cara duduk diatas bola dengan menggoyang goyangkan atau memutar panggul dan berpegangan untuk menjamin keamanan ibu. Duduk diatas bola dapat diasumsikan dengan berjongkok membuka panggul, sehingga membantu proses penurunan kepala janin. Gerakan lambat goyangan panggul dapat mengurangi rasa sakit pada saat kontraksi selama proses persalinan. Selain itu gerakan bersandar, menggoyang panggul, berlutut dan bertumpu diatas bola dapat diasumsikan dengan gerakan mobilisasi yang nyaman. Dengan menggunakan teknik Pelvic Rocking dengan Birthing Ball selama proses persalinan diharapkan kenyamanan ibu terjaga sehingga mempercepat proses persalinan.

\section{Analisis Bivariat}

\section{a. Hubungan Teknik Pelvic Rocking Dengan Birthing Ball Terhadap Lama Persalinan Kala I Fase Aktif}

Tabel 3. Hasil Analisis Bivariat

\begin{tabular}{lccc}
\hline Metode & N & $\begin{array}{c}\text { Mean } \\
\text { Rank }\end{array}$ & $\begin{array}{c}\text { Sum of } \\
\text { Ranks }\end{array}$ \\
\hline $\begin{array}{l}\text { Teknik } \\
\text { Konvensional }\end{array}$ & 15 & 19,73 & 296,00 \\
Pelvic Rocking & 15 & 11,27 & 169,00 \\
\hline Total & 30 & & \\
\hline P value $=0,006$ & & &
\end{tabular}

Tabel 3 menunjukkan bahwa responden yang menggunakan teknik konvensional dengan berjalan - jalan dan berdiri memiliki mean sebesar 19,73 dan responden yang 
menggunakan teknik Pelvic Rocking dengan Birthing Ball memiliki mean sebesar 11,27 dan hasil $p$ value adalah 0,006; dengan demikian dapat disimpulkan bahwa ada perbedaan bermakna lama persalinan kala I fase aktif pada ibu dengan teknik konvensional dengan berjalan - jalandan berdiri dengan teknik Pelvic Rocking dengan Birthing Ball.

Posisi upright dengan duduk diatas birthing ball atau disebut teknik pelvic rocking dan berjalan - jalan, berdiri, sama - sama dalam posisi tegak. Keduanya memberikan efek mempercepat proses persalinan. Namun, posisi duduk diatas bola dengan pelvic rocking lebih disukai karena ibu lebih rileks dan tidak mudah lelah. Dengan duduk ibu tetap dapat membantu penurunan kepala dengan gravitasi tetapi tidak lelah karena tidak membawa beban perut. Sehingga posisi ini membuat ibu lebih bertahan lama untuk dalam posisi upright.(Sherwood, 2012)

Salah satu faktor yang mempengaruhi lama persalinan adalah posisi persalinan.(Bobak, 2009). Sedangkan penelitian Wigand and Leight, 2012 mendapatkan hasil bahwa posisi tegak dalam persalinan kala I fase aktif akan memperpendek waktu persalinan. Posisi berjalan - jalan, duduk, dan teknik pelvic rocking merupakan posisi upright dalam persalinan. Semua posisi diatas memiliki pengaruh baik dalam proses mempercepat lama persalinan, namun sisi kenyamanan menjadi alasan dalam memilih posisi upright selama proses persalinan. Duduk bersandar, berpegangan pada sisi tempat tidur ataupun menggoyang - goyangkan panggul memberikan sensasi tersendiri kepada ibu bersalin. Mereka akan lebih rileks dengan menggoyangkan panggul.

Penambahan ukuran rongga panggul saat melakukan pelvic rockingmenjadikan ibu menjadi rileks dan melatih otot-otot polos yang terdapat di dalam rongga panggul.Ligamentum sakrotuberosum dan ligamentum sakrospinosum yang terlentang dari bagian lateral sakrum dan koksigis menuju spina iskiadika mempengaruhi persendian pada tulang panggul. (Cunningham, 2014).

Duduk diatas bola dapat diasumsikan dengan berjongkok membuka panggul, sehingga membantu proses penurunan kepala janin. Gerakan lambat goyangan panggul dapat mengurangi rasa sakit saat kontraksi. Selain itu gerakan bersandar, menggoyang panggul, berlutut dan bertumpu diatas bola dapat diasumsikan dengan gerakan mobilisasi yang nyaman.

\section{SIMPULAN DAN SARAN}

\section{a. Simpulan}

1) Sebagian besar responden yang menggunakan teknik konvensional dengan berdiri dan berjalan mengalami persalinan normal sejumlah 6 responden (40\%).

2) Sebagian besar responden yang menggunakan teknik Pelvic Rocking 
mengalami persalinan cepat sejumlah 10 responden $(66,7 \%)$.

3) Ada Pengaruh teknik Pelvic Rocking dengan Birthing Ball terhadap lama persalinan kala I fase aktif denganp-value sebesar 0,006.

\section{b. Saran}

1) Penolong persalinan dapat menggunakan teknik Pelvic Rocking dengan Birthing Ball sebagai alternatif dalam mempercepat persalinan kala I fase aktif.

2) Teknik Pelvic Rocking dengan Birthing Ball bersifatpraktis dan efektif dalam mempercepat proses persalinan kala I, sehingga dapat disosialisasikan kepada ibu hamil.

\section{DAFTAR PUSTAKA}

Aprilia,Yesie. (2011) .GentleBirthMelahirkan Tanpa Rasa Sakit.Jakarta:Gramedia WidiasaranaIndonesia

Bobak, M. Lowdermilk,Jensen MD. (2009). Buku Ajar Keperawtan Maternitas. Jakarta: EGC

Cuningham, F, G, Mc. Donal Pc. Gant Nf. (2014)Williams Obstetric. Edisi ke 24. Jakarta : EGC

Dinkes, Jateng. Profil Kesehatan Provinsi Jawa Tengah Tahun 2017. Semarang : Dinkes Jateng
James, et al. (2009). Prevent Complications of Pregnancy-Associated Hypertension. http://www.nejm.org/doi/full/10.1056/N EJMoa0908056\#t diakses 10 Januari 2018

Oxorn.(2010).Ilmu Kebidanan: Patologi \&Fisiologi Persalinan, Human Labor andBirth.Yogyakarta:Yayasan EssentiaMedica (YEM).

Saifuddin, A. B., H.Wiknjosastro, G., Affandi, B., \& Waspodo, D. (2010). Buku panduan praktis pelayanan kesehatan maternal dan neonatal. Jakarta: PT Bina Pustaka Sarwono Prawirohardjo

Sinsin, I. (2008). Seri Kesehatan Ibu dan Anak, Masa Kehamilan dan Persalinan. Jakarta: PT.Gramedia

Sherwood, L. (2012). Fisiologi Manusia dari sel ke sel. Jakarta : EGC.

Sulistyawati,A. (2010) .Asuhan KebidananPada $\mathrm{Ibu}$

Bersalin.Yogyakarta:SalembaMedika.

Theresa Jamison. (2004). Yoga For Pregnancy: Vitality Relaxation Balance.Australia: Hinkler Books Pty LTd.

Varney, H. (2009) . Buku Ajar Asuhan Kebidanan. Edisi 4. Jakarta : EGC

Wigan,Leigh (2012). Position in Labour. Obstetrics \& Gynecology Department. 